\title{
レーザークリーニングによる鋼構造物のメンテナンス
}

藤田和久 ${ }^{1}$, 豊澤一晃 ${ }^{2}$, 沖原 伸一朗 ${ }^{1}$, 前橋 伸光 ${ }^{3}$,

高原 和弘 ${ }^{3}$, 秋吉 徹明 ${ }^{3}$

1光産業創成大学院大学 ( $\bar{T} 484-1202$ 静岡県浜松市西区呉松町1955-1)

${ }^{2}$ (株) トヨコー（４４17-0047 静岡県富士市青島町39）

${ }^{3}$ (株) トヨコー 浜松研究所 (

\section{Laser Cleaning as Maintenance for Large Steel Structures}

\author{
Kazuhisa FUJITA, ${ }^{1}$ Kazuaki TOYOSAWA, ${ }^{2}$ Shin-ichiro OKIHARA, ${ }^{1}$ Nobumitsu MAEBASHI, ${ }^{3}$ \\ Kazuhiro TAKAHARA, ${ }^{3}$ and Tetsuaki AKIYOSHI ${ }^{3}$ \\ ${ }^{1}$ The Graduate School for the Creation of New Photonics Industries \\ 1955-1 Kurematsu-cho, Nishi-ku, Hamamatsu, Shizuoka 431-1202 \\ ${ }^{2}$ Toyokoh Co., Ltd., 39 Aoshima-cho, Fuji, Shizuoka 417-0047 \\ ${ }^{3}$ Hamamatsu Laboratory, Toyokoh Co., Ltd., G-2, Techno-frontier Hamamatsu \\ 1-4-10-9 Shinmiyakoda, Kita-ku, Hamamatsu, Shizuoka 431-2103
}

(Received March 16, 2017)

\begin{abstract}
Repainting steel surfaces to prevent corrosion is one maintenance method for such large steel structures as old bridges. Unfortunately, the surface preparation process for repainting has workability and environment problems, despite using the highest-grade treatment blasting method. We propose a laser cleaning system using a fiber laser to solve these problems and describe our continuous-wave laser and a circle scan design as key technologies. System safety and standardization are briefly discussed. We introduce the maintenance problems of steel bridges in Japan to show the importance of the installation of our laser device.
\end{abstract}

Key Words: Laser cleaning, Circle scan, Fiber laser, Paint removal

\section{1. はじめに}

高度成長期に多く建設されたインフラの老朽化が問 題となっている. その維持管理にCWレーザーを用いた クリーニング技術を導入しようとする試みを紹介す る。多くの新しい取り組みが含まれており，まとまっ た形で報告するのはおそらく本稿が初めてとなる。現 場の課題の理解に立った上で技術を紹介する形をとり， 前半はその課題を中心に述べ, 後半は技術の概要を説 明する。

本件の背景として産学連携が促進される環境にあっ たことは幸運であった。現場の課題を持つ著者の一部 (トヨコー) が解決策を模索するうちに光産業創成大学 院大学の著者らと出会い, 連携が開始された. 光産業 創成大学院大学は, 浜松ホトニクスが中心になっ て2005年に設立され, 光技術を用いたビジネスの実践 教育を行う博士課程のみの大学院大学である。大学側
の著者らはレーザークリーニングの専門家ではなかっ たが, 大学設立趣旨から産業界のニーズに合わせ, 専 門家でないことも利用して虚心坦懐に研究に臨んだ. 同じ静岡県内という地の利も活かし, 社会人学生とし てトヨコーから著者の一人が2008年に入学し, 教員ら とともに研究開発を進めながらOJT (On-the-Job Training) で社内への技術移転を進めてきた。本開発はトヨコー が持つ現場サイドの情報と人脈，光産業創成大学院大 学が持つ光技術と人脈が融合した結果でもあり，それ ができる環境であった。

さてその現場の話である。海に囲まれ山が多い我が国 に拈いては60万を超える橋梁があり，海からの飛来塩分 や塩化カルシウムなどの融雪剤にさらされ，保護膜であ る塗膜の劣化に伴う錆の発生により橋梁が劣化しやすい 環境にある。橋梁の寿命と言われる50年を迎える長 さ $2 \mathrm{~m}$ 以上の橋梁は，2023年には全体の $43 \% ， 2033$ 年に は67\%である ${ }^{\dagger 1}$. 老朽化に伴い通行規制がある橋梁 $(15 \mathrm{~m}$

${ }^{\dagger 1}$ 国土交通省 : 道路構造物の現状(橋梁) http://www.mlit.go.jp/road/sisaku/yobohozen/yobo1_1.pdf 
以上) は2013年に 1,381 橋あり年々増加している 交通白書が2013年を「社会資本メンテナンス元年」と位置 づけたように，事後保全から予防保全，ライフサイクル コスト低減に資する維持管理手法が今後さらに重要とな る.

日本における新設の橋の長さの経時変化 ${ }^{1)}$ Fig. 1 に 示す。高度経済成長期(1955年から1973年)に大幅に建設 が増加しており，その後も長く持続している。鋼橋(図 中Steel) や鉄筋コンクリート $(\mathrm{RC})$ 橋から始まり, より加 重に強く橋脚間の長距離化が可能なプレストレストコン クリート $(\mathrm{PC})$ 橋が多く建設されるようになってきては いるが，それでも鋼橋は主要な橋梁種である。これらが 全て維持管理対象であり, 経年につれてその重要性は増 している.

橋梁などの鋼構造物の主な維持延命手法は塗装の塗替 えによる防食性能の確保である。污れや錆, 古い塗膜を きれいに除去して鋼の素地を出す「素地調整」を行い, 再 塗装を行うことで確保されるが, 現状の素地調整法の問 題点を解消する名案の登場が期待されている状況であ る.

この素地調整には安全性の確保も急務である。含鉛塗 料(鉛系錆止め塗料) といった古い塗料の除去においては 作業員の鉛中毒が危惧され²)，2014年に厚生労働省と国 土交通省が対策を通達している3 路3号渋谷線の火災事故は, 引火性の高い薬品が加熱し た照明器具に触れたのが原因で†3, 剥離する塗膜の飛散 防止薬剤といわれている。現場における様々な面の安全 確保には，有効な手立てが待ち望まれているのが現状で ある。

このような背景から著者らは, 発展著しい高出力レー

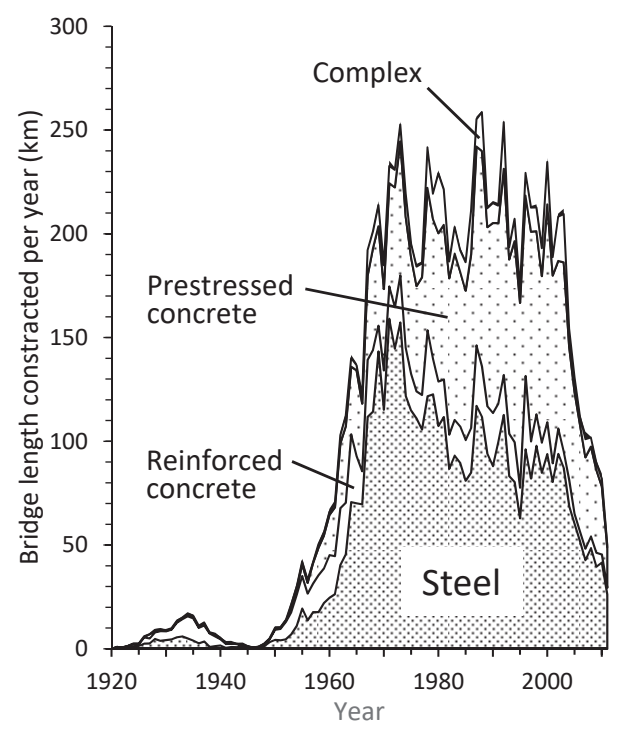

Fig. 1 Bridge length constracted per year in Japan for several kinds of bridges. The authers made on the basis of the data in Ref. 1.
ザー技術の利用に着目し，安全に作業ができる素地調整 法の開発と実用化に取り組んでいる。もちろん，このよ うな取り組みは今までになく初めての試みである。2章 では鋼構造物の維持管理に関する現状についてより詳し く述べ, 課題を明らかにする。 3章ではその解決手段と してCW円環スキャンのレーザークリーニングを提案 し, その特徴やシステム安全の取り組みについて述べ, それらの効果や広がりに触れる。

\section{2. 鋼構造物維持管理の現状と課題}

\section{1 素地調整とは}

塗替えは, Fig. 2 に示すように, 素地調整と(再)塗装 の2工程に分けられる. 素地調整とは太陽光や風雨等に より劣化した塗膜や錆をきれいに除去し, 塗装がのりや すい表面を作ることをいう。塗料は水や酸素などが鋼材 表面に到達することを阻害し，電気化学的に発生する鋼 材の腐食を防止する役割を担う。とはいえ若干の浸透が あって完全遮断は困難なため徐々に腐食が進んだり, 沿 岸部などの飛来塩分が多い環境では防食性能はさらに低 下したりするのが一般的であり, そのため塗膜は鋼材の 劣化を遅らせる機能を担う消耗的な役割を演じている.

時間と共に劣化していく防食性能が維持管理レベル (Fig. 3 のcontrol level)を下回る前に塗替えを行うことに よって性能を定期的に回復させている. しかしながら, 実際にはFig. 3 の破線のように塗替え時の性能回復が不 十分であることが多く，そのため塗替え間隔が徐々に短 くなったり，塗替えをしても性能が十分に回復しなかっ たりと, 問題が生じてきている4).

理由は古い塗膜や錆の不完全除去である。そのまま新 しい塗膜が表面を覆っても，わずかながらに浸透してく る水分が到達したとき，残った錆や古い塗膜に残ってい る塩分などから電気化学的な腐食反応が進展し, ふくれ 錆が塗膜を内側から押し上げ，剥がれが発生してしま

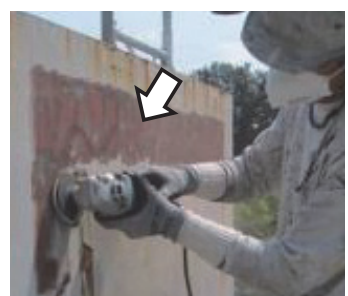

(a)

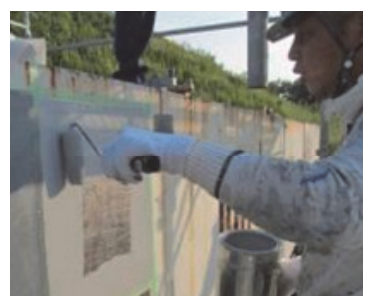

(b)
Fig. 2 Coating replacement consists of two processes of surface preparation (a) and repainting (b). The grinder commonly used in the process (a) gives lower cost but lower quality of the 3rd grade of the cleanness as the surface preparation. The brown region (white arrow) on the surface in (a) shows non-damaged under-coat after removing damaged top-coat by the grinder in the grade.

\footnotetext{
†2 国土交通省 : 全国橋梁の通行規制橋梁数の推移 http://www.mlit.go.jp/road/sisaku/yobohozen/yobo3_1.pdf

${ }^{\dagger}$ 首都高速道路株式会社：3号渋谷線淽谷入口付近の火災損傷状況の概要，平成26年3月22日

http://www.shutoko.co.jp/ /media/pdf/corporate/company/press/h25/03/22_03222002_02_2.pdf
} 


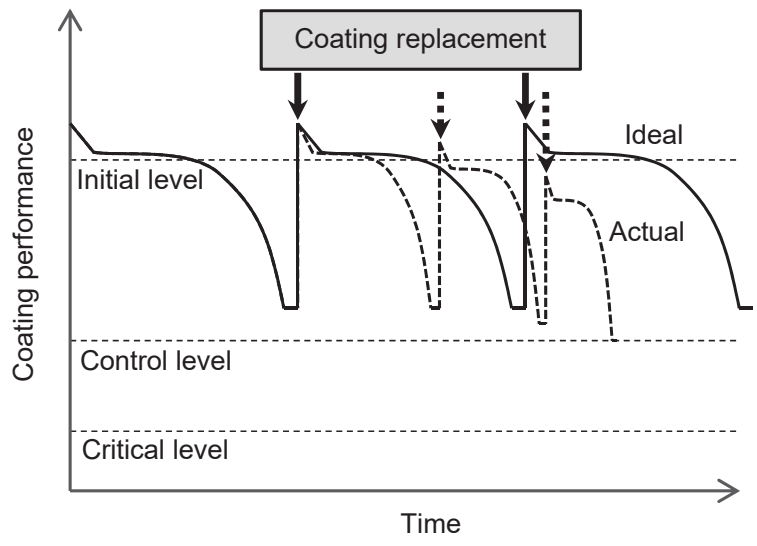

Fig. 3 Coating performance for protection of steel structure degrades and can be recovered by the coating replacement. The problem is that the actual performance curve does not follow the ideal one.

う. 質の高い素地調整が求められている所以である.

素地調整にはグレードがある。国際規格(ISO 8501)や スウェーデン規格 (SIS 005900$)$ をベースに日本では鋼 道路橋塗装便覧などで規定され，高品質の1種ケレン(ク リーンが語源といわれる)など4種類で運用されてい る ${ }^{4)}$. 比較的軽度な劣化に対しては, 表面近傍の劣化膜 のみをグラインダーなどの動力工具を用いて除去する 3 種ケレンが，その安価さ故に多く採用されている (Fig. 2 (a))

\section{2 素地調整の課題}

3種ケレンは比較的安価ではあるが，錆は完全には除 去されないため, 再塗装1年後に錆が表面に発生してし まう場合もある。よって1種ケレンが大変重要であり, 数 $\mathrm{mm}$ 以下の研削材をエアーで飛ばして表面を削るブラ ス卜工法が使われるようになってきているが課題もあ る。橋梁の細かく入り組んだ狭隘部には研削材が当たり にくく，やむを得ず3種ケレンによる対応となる場合が ある，狭溢部は構造的に重量を支える機能がある重要な 箇所であり，維持管理にとって最優先箇所である。にも かかわらず3種ケレンによる対応という現状は，適切な 手段がなくて困っているということを強く示している。

粉塵発生下で防護服を着たブラスト作業では, 大量の 材料を高速で吹き付ける反動に抗した作業でもあり， 1 時間程度で交代に至るハードさがある，少子高齢化で厳 しい作業を担う人材確保が困難になってきており, 作業 環境を抜本的に改善する新たな工夫が必須である。

\section{3. レーザークリーニングの提案}

\section{1 ハンディ高出力レーザースキャンシステム} レーザーを用いたこれまでにない全く新しいクリーニ ング手法を構築した，現在，試験施工レベルにあるクー レーザー(CoolLaser) システムである。3Kと呼ばれる典 型的な職場環境のイメージを払拭して, 誰もが格好い い，使ってみたいと思えるようなものづくりを心がけて いる. そのシステムの概要をFig. 4 に示す. 作業員が手
で持つレーザーヘッド(Fig. 4(a)，（b))からレーザー光 が出射され，そのレーザー光はシステム車両に搭載され たファイバレーザー装置から光ファイバを経由して作業 員の手元に届くしくみになっている (Fig. 4(c)). システ ム車両にはレーザー装置に加え, その冷却機, コンプ レッサや発電機など, 運転に必要な装置が全て搭載さ れ，橋梁現場周辺への現実的なアクセスと運用を可能に している。伝送用の光ファイバは長さ $100 \mathrm{~m}$ を実現し， 試験施工に供されている.

ドライヤーのようなgun 形状が一般的となるこういっ たレーザーヘッドについて，本システムではその基本概 念の段階から筒状にこだわっている(Fig.4(a)，（b))。1 種ケレンのブラスト工法では，エアーに乗せた研削材が 吐出するホース状のものを手で持って作業する。そう いった既存イメージを取り込みつつ，現場における新規 導入で違和感を持たせないような工夫をしている。清潔 感のある白衣の作業員がレーザーヘッドを手で持って作 業する(Fig. 4(b)).

光は質量がなく運動量も微小なため, レーザー照射に よる作業員への反動は事実上なく，照射したレーザー光 は熱となって消えてなくなるので，ブラスト法の研削材 などの二次廃棄物が生じることはない，生じるのは粉の ようになった塗膜や錆のみである。 クリーンルームで 実験するようなレーザー研究者の立場からするととんで もない污染になるが，屋外の土木建設分野からすればと てもクリーンな工法という感覚のようである。ブラスト 工法では1平方メートル処理に対し $\mathrm{mm}$ 以下の粒のよう な研削材を $30 \mathrm{~kg}$ 程度使用することが通常であるが，こ れらが一切不要であることがクリーンさを際立たせてい るようである。最近ではこれらを同時に吸引する機構も 追加し，作業員を粉塵環境から守るしくみを構築してい る.

レーザーによるクリーニングのもう一つの特徵は，入 り組んだ箇所の塗膜や錆がきれいに除去できることであ る。その例をFig. 5 示す. 同図(d)ではボルトの溝と いったブラストの研削材が奥まで入らないような細かく

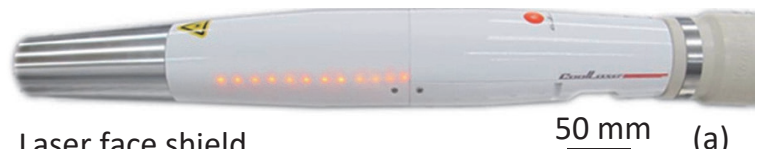

Laser face shield (a)

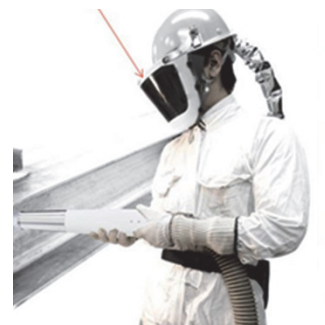

(b)

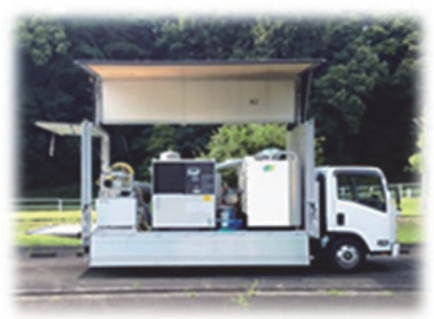

(c)
Fig. 4 "CoolLaser" system developed by the authors. The light-weight simple laser head (a) can be easily treated for a worker with the laser face shield supplying filtered air for safety (b). All the system on board (c). 


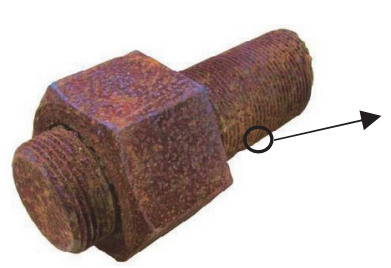

(a)

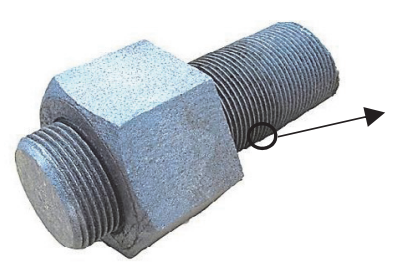

(c)

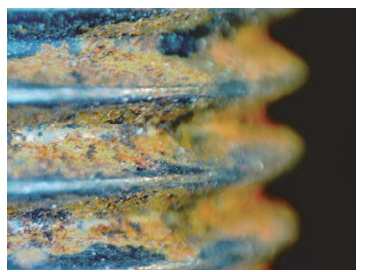

(b)

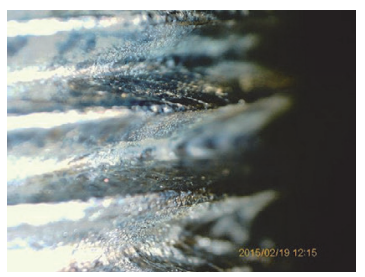

(d)
Fig. 5 A set of a rusted screw and nut before (a) and after (c) the laser cleaning, and their close-ups of the screw surfaces (b) and (d) respectively. The Laser method can clean such narrow screw valleys although the blasting method cannot due to the finite scale of the grit.

入り組んだ箇所のクリーニング例である。これは橋梁の ボルト部分などの狭隆部向けに有用である.

作業員の安全確保のため, レーザー光の波長におい て6以上の光学濃度 $(\mathrm{OD}$ 值) を持ち, かつ発生粉塵からの 保護のために清浄空気供給 (HEPAフィル夕使用) 機能を 持たせた専用のフェイスシールドを専門メーカと共同開 発した(Fig.4(b))。目の保護にはゴーグルタイプが安定 していて使いやすいものの, 屋外環境にあっては自身の 汗で量りやすい状況にもなり得ることから, 頭部全体の 冷却も兼ねた清浄空気の供給と, 通常の眼鏡との余裕あ る併用もできるよう, フルフェイス型としている。 どな たにも長時間取り回しやすい作業ができるように、レー ザーヘッドの重量も $2 \mathrm{~kg}$ 以下で構成した。レーザー出射 のスイッチは作業時以外には自然とオフになる工夫を施 し, 安全に配慮している。

とはいえ，屋外現場に扔ける高出力レーザーを用いた 作業の安全確保にはな持特段の配慮が必要である。作業 員の装備や周囲との遮蔽, インターロックなど個々の対 策に加え, システム全体に対する安全確保という捉え方 が重要である，そこで著者らは，宇宙分野等で利用が盛 んなシステム安全 ${ }^{5)}$ の考え方を専門家の指導により構築 中である. 法令などの要求への対応はもち万ん, 各作業 工程に潜むハザードを洗い出し，そのリスク評価の下， 故障の木解析により特定した原因をハード・ソフトの面 から対策・検証することでシステムの安全を確保するも のである.

新しい技術の導入には, 多くの周辺事情も総合的に配 慮する必要性があり, それらを通して何よりも担い手が 集まるような環境を整える必要がある.
3.2 CWレーザーの円環スキャン

このように新たに開発したレーザークリーニングシス テムであるが，レーザー照射による表面クリーニングの 歴史自体は意外と古い，1960年のレーザー発明後，例え ば1969年にQスイッチパルスレーザーを用いた金属表面 上のコンタミ除去が試され6 ${ }^{6}$ ，1973年には大理石や石像 などの文化財表面のルビーレーザーなどを用いたクリー ニングが新提案として報告されている7゙. その後, 文化 財保存については多くのクリーニングが実施され゙，欧 州の専門会議“4では作業講習会も実施されて抢り, 文化 財の維持管理技術としてレーザー利用が定着してきてい る. 高ピークパワーによるアブレーション除去が可能で かつ熱影響を抑制できる特徵からパルスレーザーの利用 が一般的で，スキャン機能を備えるレーザークリーニン グ装置として多くの製品が上市され，工業的にも多分野 にわたり普及している ${ }^{8,9}$.

著者らもこのような先人たちの成果を利用させていた だくべく，パルスレーザーを用いたいくつかのクリーニ ング装置を当初試したものの, 要求する施工スピードに 足るものは当時皆無であった，これは施工の時間スケー ルの中で圧倒的な大エネルギーの投入が必須との示唆で あり，すなわち高平均パワーが求められることになる。 そこで，より安価でパワーの大きいCW装置の利用でエ ネルギーを確保しながら，熱影響に関してはスキャン方 法の工夫などで対応できるのではとの着想を得る，具体 的には，製品が成熟してきたCWファイバレーザー装置 を利用し, 次に述べるスキャン機構を導入することで, 前節のようなクリーニングができるようになった ${ }^{10)}$. レーザー除染の分野では峰原が同様の着想をしてい $ろ^{11,12)}$.

プロセッシングに必要なパワー密度を確保しつつ広い 面を処理するためにはレーザー光のスキャンが必須とな る. 従来のスキャン方式としては, レーザーマーキング (印字)など精密制御に多用されるガルバノ方式や，スー パーのレジでバーコード読取りに使用される簡易なポリ ゴン方式が一般的である。しかしこれらの方式は, 屋外 の狭い場所に打ける作業向けとして堅牢性や小型化に難 があり，新たな発想が必要であった。 そこでFig. 6 に示 す円環照射(円環スキャン方式)を採用し，Fig. 4 に示し たような，手で持ちやすい堅牢なレーザーヘッドを実現 した。レーザーヘッド内で回転するプリズム (Fig. 6(a)) により屈折されたレーザー光が円周上を走る円環スキャ ンとなり、ヘッドを横に動かせば面の処理が可能となる 仕組みである(Fig. 6(b)).

このCWの使用と円環スキャン方式を基礎とすること で，例えばFig. 5 で示したネジ以外にも様々なクリーニ ング用途に高い処理速度で対応できる可能性も拓かれる ことになった。

\section{3 効果と広がり}

橋梁に抢ける防錆には, 錆に加え塩分の除去も重要で

\footnotetext{
${ }^{\top 4} 11$ th Conference on Lasers in the Conservation of Artworks (LACONA XI) in 2016, http://lacona11.org/
} 


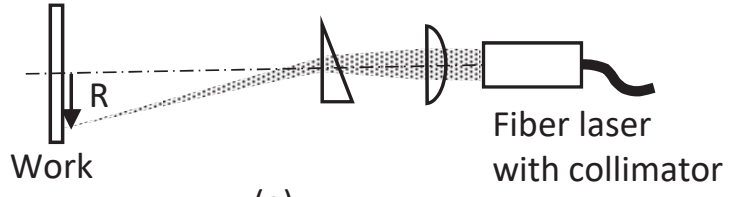

(a)

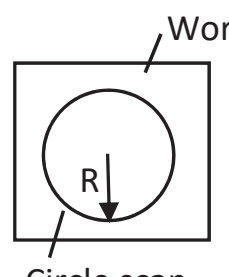

Circle scan

(b)

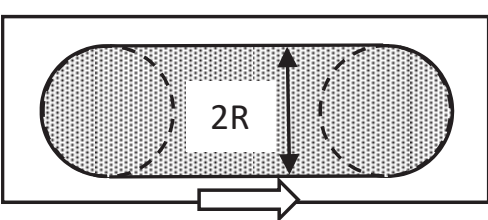

(c)
Additional scan

Fig. 6 Principle of the circle scan using rotation of a wedge prism (a). The focued laser beam makes a circle trajectory on the work, and the additional scan in one direction enables areal processing for the hatched region in (c).

ある. 水分を吸着しやすい塩分があると，やがて塗膜を 通して浸透してくる水分をその場で取り込み，水と塩素 イオンの存在により電気化学反応としての電流を増加さ せ，腐食反応を促進させてしまうからである，1 平方 メートル当り $50 \mathrm{mg}$ 以上の塩分が付着していると塗装後 早期に塗膜欠陥が生じやすいと指摘されている ${ }^{13)}$. 素地 調整時にその基準を満たさない場合には高圧水洗いなど により $50 \mathrm{mg} / \mathrm{m}^{2}$ 以下にする必要があるとされているが, 排出水に上る環境污染に留意する必要があって対応しづ らい面もあり，その場合は効果が落ちるが拭き取りなど の対応が定められている ${ }^{13)}$.

本レーザークリーニング技術では, 残留塩分濃度をド ライプロセスで基準值以下に低減・制御することが可能 である，塩分と水分がある条件下で発錆させた鉄鋼サン プルにレーザークリーニングを施し, 残留塩分の定量評 価がされている。山間部では $50 \mathrm{mg} / \mathrm{m}^{2}$ 程度の塩分付着量 であるのに対し，海岸道路上では $1000 \mathrm{mg} / \mathrm{m}^{2}$ を超える

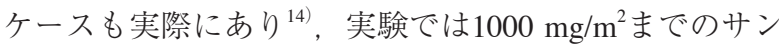
プルについて, 検出限界以下の残留塩分濃度を実証して いる，橋梁管理の立場からはこの一点だけでも高い評価 をいただくことが多い

2015年12月には, 経済産業省の新市場創造型標準化制 度における採択テーマとなり，鋼構造物においてレー ザークリーニングされた表面品質評価の標準化にも取り 組みはじめた ${ }^{\dagger 5}$.

インフラの観点からすれば，原子力発電所の廃止措置
に㧈ける除染についても利用可能性があり，表面除染の 観点から検討が進められている ${ }^{15)}$. ほかにも工業製品の 表面クリーニングなどの可能性もあり，様々な用途の広 がりが期待される。

4. まとめ

インフラ老朽化に対し，新しい維持管理手段である レーザークリーニングが提案され，その解説をした。 $\mathrm{CW}$ 利用と円環スキャンの導入により，これまでにない 高速処理の可能性を見出し, 安全や標準化への取り組み なども含め, 総合的に実用化へ向けて取り組んでいる. 本稿を機に多くのご指導をいただき，インフラ維持はじ め，社会に貢献できる技術になっていくことを望む．

謝 辞

本論文をまとめるにあたり，作図や校正の支援をいた だいた(株)トヨコーの山口彩里氏に感謝いたします。

\section{参考文献}

1) 玉越 隆史，横井芳輝：平成 25 年度道路構造物に関する基 本デー夕集，国総研資料第 822 号， 2015 .

2) 片脇 清士, 中野正則：鋼道路橋の塗替え時における含鉛 塗料の除去について（土木技術資料 55-2，2013)pp. 56

3) 厚生労働省，国土交通省：鉛等有害物を含有する塗料の剥 離やかき落とし作業における労働者の健康障害防止につい て (基安労発0530 第2号, 基安化発0530第2号, 国官技第 58 号, 2014).

4）山田 健太郎, 館石 和雄 : 橋梁の維持管理(コロナ社, 2015) p. 50

5) C. A. Ericson, II: Hazard Analysis Techniques for System Safety (JOHN WILLY \& SONS, INC., 2005).

6) S. M. Bedair and Harold P. Smith Jr.: J. Applied Physics 40 (1969) 4776.

7) L. Lazzarini, L. Marchesini, and J. F. Asmus: J. Vacuum Science and Technology 10(1973) 1039.

8）日塔 光一：レーザープロセシング応用便覧第8章1(エヌ ジーティー, レーザー学会編, 2006)p. 477.

9) 本村 孔作：第83回レーザ加工学会講演論文集（2015）89.

10）豊澤一晃, 沖原伸一朗, 藤田和久: レーザーアブレー ションによる有機物質除去の効率化に関する研究(第3回研 究・開発成果発表会, 浜松工業技術支援センター主催, ア クトシテイ浜松, 浜松市, 2010).

11）峰原 英介：デコミッショニング技報 45 (2012) 10 .

12) 峰原 英介：レーザー研究 40 (2012) 165.

13）日本道路協会編：鋼道路橋防食便覧（日本道路協会，2014） p. II-145.

14）日本道路協会編：鋼道路橋防食便覧（日本道路協会，2014） p. II-146.

15) 岡部一彦：電気評論 102 (2017) 56

\footnotetext{
${ }^{75}$ 経済産業省ニュースリリース2016年1月29日．http://www.meti.go.jp/press/2015/01/20160129001/20160129001.html
} 